DOE/EA-1130

\title{
ENVIRONMENTAL ASSESSMENT FOR THE OFF-SITE COMMERCIAL CLEANING OF LEAD AND ASBESTOS CONTAMINATED LAUNDRY FROM THE SAVANNAH RIVER SITE
}

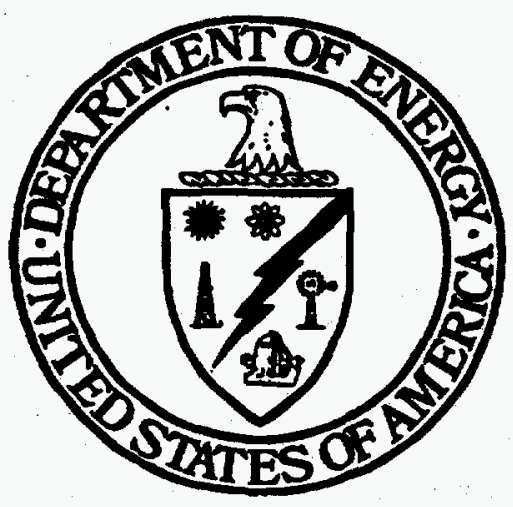

DECEMBER 1995

\section{UNITED STATES DEPARTMENT OF ENERGY SAVANNAH RIVER OPERATIONS OFFICE SAVANNAH RIVER SITE}

\section{MASTER}

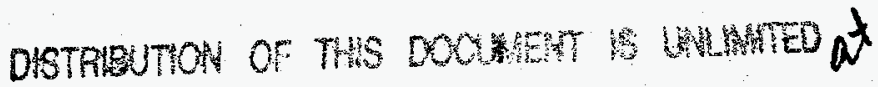




\section{TABLE OF CONTENTS}

1.0 INTRODUCTION

1.1 Background

1.2 Purpose and Need for Action

2.0 PROPOSED ACTION AND ALTERNATIVES 3

2.1 Proposed Action 3

2.2 Alternatives to the Proposed Action 4

2.2.1 No Action, Continue to Store Lead and Asbestos Contaminated Laundry and Provide Replacement Garments

2.2.2 Dispose of Lead and Asbestos Contaminated Laundry as Waste

3.0 ENVIRONMENTAL CONSEQUENCES OF THE PROPOSED ACTION AND ALTERNATIVES

3.1. Vendor Facility Operation 4

3.2 SRS Operations 6

3.3 Transportation Impacts $\quad 6$

3.3.1 Analyzed Scenario 6

3.3.2 Assumptions 16

3.3.2 Consequences 7

3.4 Human Health Effects

3.5 Environmental Consequences of the Alternatives 7

3.6 Cumulative Impacts 9

4.0 REGULATORY AND PERMITTING PROVISIONS CONSIDERED 9

4.1 National Environmental Policy Act of 1969 as amended 9

4.2 Occupational Safety and Health Act of 1970

$\begin{array}{lll}5.0 & \text { REFERENCES } & 10\end{array}$ 



\section{LIST OF TABLES}

Table 1. Alternative to Dispose of Lead and Asbestos Contaminated Laundry as Waste.

PAGE 5

Table 2. Non-hazardous Material Accident Consequences Associated with the Proposed Action.

\section{LIST OF FIGURES}

Figure 1. Map illustrating the general locations of the various site areas participating in the commercial laundry services at the Savannah River Site, South Carolina. 


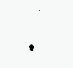




\subsection{INTRODUCTION}

This Environmental Assessment (EA) has been prepared by the Department of Energy (DOE) to assess the potential environmental impacts of off-site commercial cleaning of lead and asbestos contaminated laundry generated at the Savannah River Site (SRS), located near Aiken, South Carolina (Figure 1). The proposed action constitutes an addition to the already-implemented action of sending controlled and routine SRS laundry to an off-site commercial facility for cleaning. This already-implemented action was evaluated in a previous EA (i.e., DOE/EA-0990; DOE, 1994) prepared under the National Environmental Policy Act of 1969 (NEPA).

\subsection{Background}

SRS personnel are required (e.g., under Occupational Safety and Health Administration or OSHA regulations) to wear protective clothing for activities involving the handling and removal of both lead and asbestos. This work can occur in both radiological and nonradiological areas on site. Within this range of working conditions, this type of clothing can vary from minimal (e.g., coveralls without sleeves) to more advanced (e.g., coveralls with sleeves, hoods and booties) levels of protection.

The types of work on SRS which could generate lead contaminated laundry would include the following:

- Abrasive blasting

- Torch cutting on painted steel

- Manual demolition of lead-painted surfaces

- Dry scraping and sanding of lead-painted surfaces

- Heat gun removal

- Spraying of lead paints

- Handling stored lead bricks, lead shot, lead shielding, and lead sheeting

- Machining of soft lead

Additional site activities which might generate lead would include waste site remediation projects under either the Comprehensive Environmental Response, Compensation, and Liability Act or the Resource Conservation and Recovery Act. All of these activities could occur in radiologically contaminated areas.

Site activities which would generate laundry contaminated with asbestos would include:

- Asbestos abatement

- Removal of non-friable asbestos

- Work involving asbestos-containing building material

Abatement activities involve the removal of asbestos containing boiler materials and other thermal systems insulation, and the removal of pipe lagging. These are Class I OSHA jobs which require disposable clothing which site personnel would wear over coveralls that may have to be laundered if the disposables get torn. The non-friable asbestos removal would involve the intact extraction of asbestos-containing building material (e.g., transite sheets, floor tiles). This would be a Class II OSHA job and may require laundering of coveralls depending upon the release of fibers during the work activities. Work on asbestos-containing building material would involve activities such as drilling holes in transite, removal of floor tiles, and removal of roof tars. These would be Class III OSHA jobs which require that all coveralls be laundered as potentially contaminated. 


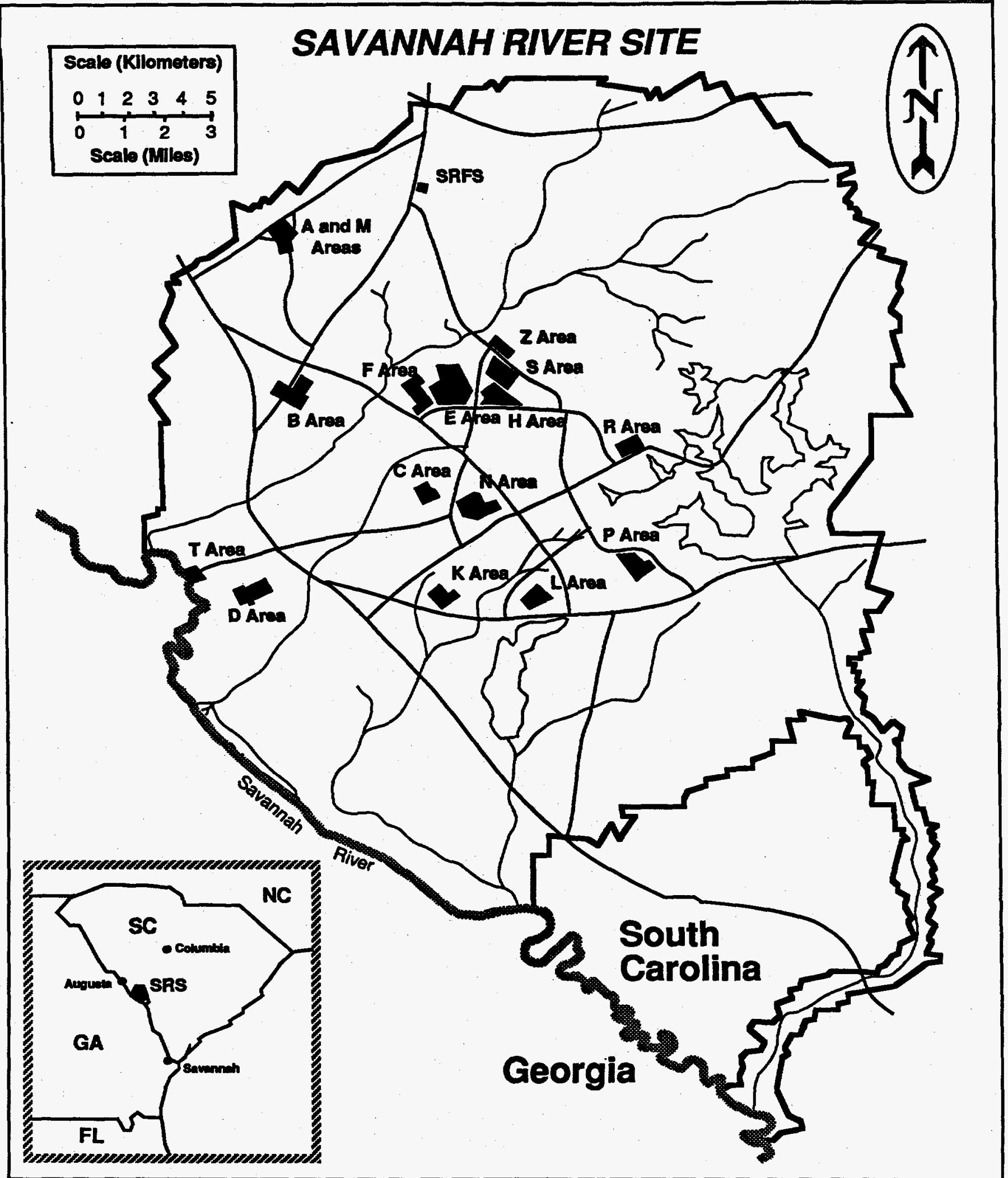

Figure 1. Map illustrating the general locations of the various site areas participating in the commercial laundry services at the Savannah River Site, South Carolina. 
Historically on SRS, once worker protective clothing had been used in either lead or asbestos handling/removal activities, it was not laundered but rather disposed of as waste in one of the site's waste management/disposal facilities. More recently, these garments have been appropriately containerized and placed in indefinite storage in F Area. With either the previous or current practices for dealing with the contaminated articles of protective clothing, replacement garments were provided for subsequent lead and asbestos handling/removal activities. Laundering technology exists which would enable the cleaning and monitoring of both lead and asbestos contaminated controlled and routine protective clothing, thereby allowing such garments to be reissued for use by SRS personnel. The cleaning of these site-generated types of contaminated laundry was determined to be a viable alternative to the current practice of containerization and indefinite storage.

\subsection{Purpose and Need for Action}

The purpose of the proposed action is to provide SRS with a cost-effective means of cleaning the protective clothing used in lead and asbestos handling/removal activities on site. DOE needs to eliminate the unnecessary costs associated with the current practice of purchasing replacement garments and not reusing serviceable protective clothing which can be laundered for reuse.

\subsection{PROPOSED ACTION AND ALTERNATIVES}

\subsection{Proposed Action}

The proposed action is to transport the SRS-generated lead and asbestos contaminated controlled and routine laundry to an off-site vendor (subcontractor) facility (i.e., with all required Nuclear Regulatory Commission, state, and local licenses and/or permits) with the other site laundry for cleaning. The laundered protective clothing would then be reissued for use in site worker activities. The scope of the proposed action within this EA would be implemented within the existing contract for the cleaning of all of the site's laundry.

Approximately ten bags of lead and asbestos contaminated laundry are currently generated on SRS on an average monthly basis. The work sites where this laundry is generated can include any of the developed areas on site (Figure 1). In addition, approximately 120 bags of containerized contaminated laundry are currently in storage in F Area. This overall volume encompassed by the proposed action would initially create an increase of slightly more than two percent over the current volume of site-generated laundry. After the current stored inventory has been laundered, the monthly increase over the present site generation volume would be less than 0.2 percent. The overall scope of the off-site commercial cleaning of SRS controlled and routine laundry was defined in DOE (1994). It should be emphasized that the scope of the proposed action in the present EA does not include the specific lead and asbestos worker activities noted in Section 1.1. Such activities would be covered under separate SRS NEPA documentation.

Within this EA, the impact analyses of the proposed action used the location of the existing vendor facility in Columbia, South Carolina, as the off-site commercial destination of the transportation of the site's laundry. However, the potential currently exists for an off-site vendor laundry facility to be constructed at a new location (e.g., Aiken, South Carolina) along the analyzed route between SRS and the existing facility in Columbia. Should the off-site location change from the existing site to one along the analyzed route, the transportation impacts would be bounded by analyses presented in this EA. 


\subsection{Alternatives to the Proposed Action}

In accordance with NEPA regulations, DOE examined the following alternatives to the proposed action:

- No action, continue to store lead and asbestos contaminated laundry and provide replacement garments

- Dispose of the lead and asbestos contaminated laundry as waste

\subsubsection{No Action, Continue to Store Lead and Asbestos Contaminated Laundry and Provide Replacement Garments}

One alternative to the proposed action is to take no action. This would consist of continuing to containerize and store the lead and asbestos contaminated laundry as per the current site practice, and to provide replacement garments. The site would continue to assume the increased cost of purchasing replacement garments. Further, the site would continue to accrue bags of contaminated laundry at the rate of approximately ten bags per month.

\subsubsection{Dispose of the Lead and Asbestos Contaminated Laundry as Waste}

Another alternative would be to dispose of the subject laundry as waste in an appropriate manner. The appropriate disposal methods for each waste type are listed in Table 1 . Increases to the various site waste streams are also provided in Table 1. This alternative would also require the purchase of replacement garments.

\subsection{ENVIRONMENTAL CONSEQUENCES OF THE PROPOSED ACTION AND ALTERNATIVES}

The SRS encompasses approximately 80,535 hectares $(199,000$ acres) in southwestern South Carolina, approximately $\mathbf{4 0} \mathrm{km}$ (25 mi) southeast of Augusta, Georgia along the Savannah River (Figure 1). SRS contains five nuclear production reactor areas; two chemical separations areas; waste processing, storage, and disposal facilities; and various supporting facilities. A comprehensive discussion of SRS and associated environs is presented in the Waste Management Final Environmental Impact Statement (DOE, 1995), and in several SRS environmental information documents (WSRC, 1989a, 1989b; Amett et al., 1994; Wike et al., 1994). The most recent socioeconomic survey of the six-county SRS area of influence contains additional information (HNUS, 1992). The locations of the various site areas involved in the generation of lead and asbestos contaminated laundry are depicted on Figure 1.

\subsection{Vendor Facility Operation}

The vendor facility operation is considered to be an ongoing activity that is beyond the scope of this EA. It can be assumed that the operation of that facility would be comparable to the former SRS laundry facility in F Area, which was classified as a low hazard facility (WSRC, 1993a, $1993 \mathrm{~b}, 1993 \mathrm{c})$. Terms and conditions within the proposed contract require that the vendor be responsible for identifying and complying with all applicable laws and regulations governing the operation of the off-site facility and shipment of the controlled and routine laundry from and back to SRS. No further impact assessments of the vendor facility were undertaken within this EA process. 
TABLE 1

Alternative to Dispose of Lead and Asbestos Contaminated Laundry as Waste

\begin{tabular}{|c|c|c|c|}
\hline $\begin{array}{c}\text { Type of } \\
\text { Contaminated } \\
\text { Laundry }\end{array}$ & $\begin{array}{c}\text { SRS } \\
\text { Waste Stream }^{\mathrm{a}}\end{array}$ & $\begin{array}{l}\text { Appropriate } \\
\text { Disposal }\end{array}$ & $\begin{array}{l}\text { Approximate } \\
\text { Percent of } \\
\text { Current Annual } \\
\text { Waste Streamb }\end{array}$ \\
\hline $\begin{array}{l}\text { Lead-Contaminated } \\
\text { Routine Laundry }\end{array}$ & $\begin{array}{l}\text { Hazardous Waste } \\
\text { Heterogeneous Debris }\end{array}$ & $\begin{array}{l}\text { Off-Site Treatment } \\
\text { and Disposal }\end{array}$ & 5.7 \\
\hline $\begin{array}{l}\text { Lead-Contaminated } \\
\text { Controlled Laundry }\end{array}$ & $\begin{array}{c}\text { Mixed Waste } \\
\text { Heterogeneous Debris }\end{array}$ & RCRA Disposal & 7.7 \\
\hline $\begin{array}{l}\text { Asbestos-Contaminated } \\
\text { Routine Laundry }\end{array}$ & $\begin{array}{c}\text { Municipal Solid } \\
\text { Waste/Special Waste }\end{array}$ & $\begin{array}{l}\text { Disposal in Off-Site } \\
\text { Subtitle D Landfill }\end{array}$ & 0.006 \\
\hline $\begin{array}{l}\text { Asbestos-Contaminated } \\
\text { Controlled Laundry }\end{array}$ & $\begin{array}{c}\text { Low-Activity } \\
\text { Job Control Waste }\end{array}$ & $\begin{array}{l}\text { Volume Reduction } \\
\text { and Vault Disposal }\end{array}$ & 0.09 \\
\hline
\end{tabular}

a Based on WSRC (1994)

b Based on the assumption that these types of contaminated protective clothing are generated in equal amounts on an annual basis and WSRC (1994) 


\subsection{SRS Operations}

Overall site activities associated with the off-site commercial cleaning of SRS-generated laundry were assessed under the previous EA (DOE, 1994). Therefore, the pick-up, on-site transportation, and delivery activities are considered to be an ongoing activity which would not change as a result of the proposed action. The lead and asbestos contaminated laundry would be bagged at the work location and taken to a pick-up point for incorporation into the vendor operations. No additional impacts would be expected as a result of the proposed action.

\subsection{Transportation Impacts}

\subsubsection{Analyzed Scenario}

Currently, protective clothing contaminated with lead or asbestos is bagged and collected from various locations around SRS (WSRC, 1993a), and then brought to F Area for indefinite storage. This clothing may have been used in either radiological or non-radiological areas.

Under the action proposed in this EA, the bags containing lead or asbestos contaminated controlled or routine laundry would be placed into metal boxes at the F-Area laundry facility for shipment with other site laundry to an off-site facility for cleaning. The typical capacity of the laundry boxes is 363 to $454 \mathrm{~kg}$ ( 800 to 1000 pounds) of laundry (WSRC, 1995a). These laundry boxes would be transported on a tractor trailer truck to the off-site cleaning facility.

The consequence of transporting the lead and asbestos contaminated laundry to an off-site cleaning facility considered in this analysis is a traffic accident with the worst case being an accident resulting in a fire. An accident occurring during the outbound shipment of contaminated laundry is considered to be the bounding case because the volumes of laundry or associated levels of contamination are lower in other cases (i.e., on-site collection trips or return trip from the off-site facility).

\subsubsection{Assumptions}

As described in the previous section, it is assumed that the worst case accident scenario is a traffic accident which occurs during the outbound shipment of the contaminated laundry to the off-site cleaning facility and involves a fire. Determination of the concentration of lead or asbestos contamination seen by the exposed individual following the analyzed accident is based initially on the annual quantity of protective clothing processed for cleaning at SRS. An allowance is made for the increase in the amount of laundry which would be handled as the result of including protective clothing contaminated with lead or asbestos. Details of the assumptions made in the calculation of the accident consequences are given in the following paragraphs.

SRS normally processes approximately $1.5 \times 10^{6} \mathrm{~kg}$ (about 3.5 million pounds) of controlled and routine protective clothing annually (WSRC, 1995a). Assuming that including lead and asbestos contaminated protective clothing would increase the amount of laundry to be handled by 0.2 percent, there would be an additional $3000 \mathrm{~kg}$ shipped annually.

It has been determined that 20 shipments/month would be needed to process the current sitegenerated inventory of contaminated laundry at an off-site cleaning facility (WSRC, 1995a). It is unlikely that including the relatively small amount of additional laundry contaminated with lead and asbestos would increase this number of required shipments.

The protective clothing described in this scenario is assumed to be contaminated with either lead in powder form, or asbestos fibers. The lead contamination is assumed to consist of lead powder in 
the amount of 1 percent by weight of the lead and asbestos contaminated clothing. Additionally, it is assumed that there is approximately 1.0 gram of asbestos fibers on each typical article of asbestos contaminated protective clothing. The typical piece of protective clothing is assumed to be a pair of coveralls.

Release of lead or asbestos contamination to the atmosphere is assumed to occur only in the event of a traffic accident involving a fire in which case all of the outer packaging is breached and all of the contaminated clothing is completely incinerated. Packaging of the contaminated clothing for shipment would likely preclude the release of contamination to the atmosphere in the event of a non-fire accident.

\subsubsection{Consequences}

Using conservative assumptions, it is shown (WSRC, 1995b) that the consequences of an accident involving the typical off-site shipment of contaminated protective clothing do not present a human health hazard. The concentration of airborne lead in the area immediately adjacent to the event following the analyzed accident is shown to be $2.78 \times 10^{-3} \mathrm{mg} / \mathrm{m}^{3}$ which is small compared to the OSHA Permissible Exposure Levels -Time Weighted Average value of $0.05 \mathrm{mg} / \mathrm{m}^{3}$ (DOL, 1994). The concentration of airborne asbestos in the same area following the analyzed accident is calculated to be 0.08 fibers $/ \mathrm{cm}^{3}$ compared to a limit of 0.1 fiber $/ \mathrm{cm}^{3}$ (DOL, 1994).

These calculated values imply that further evaluation to determine accident probability and risk is unnecessary. Any lead or asbestos releases resulting from the analyzed accident are minimal and would be of little consequence regardless of the frequency of the event, the population density, or the highway distance traveled.

The primary non-hazardous material consequence is a traffic accident fatality. Table 2 provides the expected accident frequencies and numbers of accidents with fatalities. The accident frequencies (accidents/kilometer) are provided by RADTRAN (Neuhauser, 1992). The distances are provided by HIGHWAY (Johnson, 1993). The percent of tractor-trailer accidents resulting in fatalities, 7.5 percent, is from the U.S. Department of Transportation (DOT, 1989).

The values in Table 2 are for a single round trip shipment. The number of accidents is determined by multiplying the accident rate (accident $/ \mathrm{km}$ ) by the number of kilometers round trip. The number of accidents with fatalities is obtained by taking 7.5 percent of the number of accidents. The resulting number of accidents resulting in fatalities is for a single round trip shipment.

\subsection{Human Health Effects}

While exposure to lead and asbestos contamination can result in significant adverse effects on humans, the airborne concentrations of lead and asbestos resulting from a collision and subsequent fire are below the OSHA Permissible Exposure Levels and therefore do not present a hazard to those individuals that may be in the immediate vicinity of the transportation accident. As these concentrations do not present a hazard to individuals in the immediate vicinity of the release, such a release would not pose a hazard to the general public.

\subsection{Environmental Consequences of the Alternatives}

The no-action alternative would result in a continuation of the costly replacement of lead and asbestos contaminated laundry. In addition, storage capacity for the contaminated laundry would ultimately become limiting, requiring the identification of additional storage space. The alternative of treating the contaminated laundry as waste would result in an increase of from less than one up to approximately eight percent over the current SRS waste streams for the various types of 


\section{TABLE 2}

Non-hazardous Material Accident Consequences Associated with the Proposed Action

\begin{tabular}{lllll}
\hline Destination & $\begin{array}{c}\text { Distance } \\
\text { (in } \mathrm{km} \text { ) }\end{array}$ & Accident Rateb & $\begin{array}{c}\text { Number of } \\
\text { Accidents }\end{array}$ & $\begin{array}{c}\text { Number of } \\
\text { Accidents } \\
\text { Resulting in } \\
\text { Fatalities }\end{array}$ \\
\hline Columbia, SC & 274 & $1.01 \times 10^{-6}$ & $2.77 \times 10^{-4}$ & $2.07 \times 10^{-5}$ \\
\hline
\end{tabular}

Kilometers can be converted to miles by multiplying the kilometers by 0.62

b Weighted by distance for population density 
contaminated material. Certain waste streams (e.g., low-activity job control waste) require expensive off-site treatment and on-site disposal in increasingly limited vault space in E Area. This alternative also has the further expense of providing replacement garments for subsequent SRS lead and asbestos handling/removal activities.

\subsection{Cumulative Impacts}

The principal cumulative impacts from the proposed action would be an increase in the traffic accident fatality rate of less than 0.006 percent. The lead and asbestos aspect of the transportation portion of proposed action would not pose any health hazard to the general public. No latent cancer fatalities would be expected to result from the proposed action.

\subsection{REGULATORY AND PERMITTING PROVISIONS CONSIDERED}

DOE policy is to carry out its operations in compliance with all applicable Federal, state, and local laws and regulations, as well as all DOE Orders. This section provides a discussion of the major regulatory permit programs that might be applicable to the proposed action.

\subsection{National Environmental Policy Act of 1969 as amended}

This EA has been prepared in compliance with the NEPA of 1969, as amended, and the requirements of the CEQ Regulations for Implementing NEPA (40 CFR Parts 1500-1508), and DOE Regulations (10 CFR Part 1021), and DOE Order 5440.1E. NEPA, as amended, requires "all agencies of the Federal Government" to prepare a detailed statement on the environmental effects of proposed "major Federal actions significantly affecting the quality of the human environment." This EA has been written to comply with NEPA and assess the potential environmental impacts of off-site commercial cleaning of lead and asbestos contaminated laundry generated at SRS.

\subsection{Occupational Safety and Health Act of 1970}

The vendor would be responsible for complying with training regarding the handling and cleaning of lead and asbestos worker clothing as required under the Hazards Communication subpart of the Occupational Safety and Health Act of 1970 (29 CFR Part 1910.1200). 


\subsection{REFERENCES}

Arnett, M. W., L. K. Karapatakis, and A. R. Mamatey, 1994. Savannah River Site Environmental Report for 1993. WSRC-TR-94-075, Westinghouse Savannah River Company, Savannah River Site, Aiken, South Carolina.

DOE (U. S. Department of Energy), 1994. Environmental Assessment for the Offsite Commercial Cleaning of Controlled and Routine Laundry from the Savannah River Site. DOE/EA-0990, Savannah River Operations Office, Aiken, South Carolina.

DOE (U. S. Department of Energy), 1995. Environmental Impact Statement for Waste Management at the Savannah River Site, Vol. I and II DOE/EIS-0217, Savannah River Operations Office, Aiken, South Carolina.

DOL (U. S. Department of Labor), 1994. The Occupational Exposure to Asbestos - Final Rule, Occupational Safety and Health Administration, 29 CFR 1926.1101, (59 FR 40964), Washington, DC.

DOT (U. S. Department of Transportation), 1989. Accidents Reported by Motor Carriers of Property 1989. FHWA/MC-92/018. U.S. Department of Transportation, Federal Highway Administration, Office of Motor Carriers, Washington, DC.

HNUS (Halliburton NUS Environmental Corporation), 1992. Socioeconomic Characteristics of Selected Counties and Communities Adjacent to the Savannah River Site, July 1992, Halliburton NUS Corporation, Aiken, South Carolina.

Johnson, P. E. et al., 1993. HIGHWAY 3.1 - An Enhanced Highway Routing Model: Program Description, Methodology, and Revised User's Manual. ORNL/TM12124, Oak Ridge National Laboratory, Oak Ridge, Tennessee.

Neuhauser, K. S., and F. L. Kanipe, 1992. RADTRAN 4: Volume 3 User Guide. SAND89-2370; TTC-0943; UC-722. Sandia National Laboratories, Albuquerque, New Mexico.

Wike, L. D., R. W. Shipley, A. L. Bryan, J. A. Bowers, C. L. Cummins, B. R. del Carmen, G. P. Friday, J. E. Irwin, J. J. Mayer, E. A. Nelson, M. H. Paller, V. A. Rogers, W. L. Specht, and E. W. Wilde, 1994. SRS Ecology: Environmental Information Document, WSRC-TR-93-496, Westinghouse Savannah River Company, Savannah River Site, Aiken, South Carolina.

WSRC (Westinghouse Savannah River Company), 1989a. Reactor Operation Environmental Information Document, Volume I: Geology, Seismology and Subsurface Hydrology (U), WSRC-89-815, Westinghouse Savannah River Company, Savannah River Site, Aiken, South Carolina.

WSRC (Westinghouse Savannah River Company), 1989b. Reactor Operation Environmental Information Document, Volume III: Meteorology, Surface Hydrology, Transport and Impacts (U), WSRC-89-817, Westinghouse Savannah River Company, Savannah River Site, Aiken, South Carolina.

WSRC (Westinghouse Savannah River Company), 1993a. General Services Laundry Operations. Manual D1-5-3, Savannah River Site, Aiken, South Carolina. 
WSRC (Westinghouse Savannah River Company), 1993b. Hazards Assessment Document, 723-F Laundry Facility. WSRC-TR-93-310, Savannah River Site, Aiken, South Carolina.

WSRC (Westinghouse Savannah River Company), 1993c. Calc-Note: Hazards Assessment for the 723-F Laundry Facility. SRT-WAG-93-9009, Savannah River Site, Aiken, South Carolina.

WSRC (Westinghouse Savannah River Company), 1994. Thirty-Year Solid Waste Generation Forecast at SRS, Revision 4, July 1994, WSRC-RP-94-532, Westinghouse Savannah River Company, Savannah River Site, Aiken, South Carolina.

WSRC (Westinghouse Savannah River Company), 1995a. Specification for the Procurement of Commercial Laundry Services, Specification No.: WSRC-TS-4, Revision 2, Aiken, South Carolina.

WSRC (Westinghouse Savannah River Company), 1995b. Determination of Human Health Effects Resulting from a Transportation Accident Involving Lead and Asbestos Contaminated Clothing (U), S-CLC-G-00093, Aiken, South Carolina. 



\section{Finding of No Significant Impact for the \\ Off-Site Commercial Cleaning of \\ Lead and Asbestos Contaminated Laundry from the Savannah River Site}

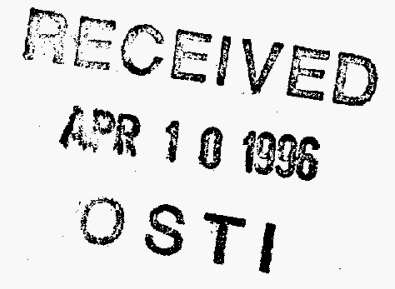

Agency: $\quad$ U. S. Department of Energy

Action: Finding of No Significant Impact

Summary: The Department of Energy (DOE) has prepared an environmental assessment (EA) (DOE/EA-1130) for the proposed off-site commercial cleaning of lead and asbestos contaminated laundry generated at the Savannah River Site (SRS), located near Aiken, South Carolina. The proposed action constitutes an addition to the already-implemented action of sending controlled and routine SRS laundry to an off-site commercial facility for cleaning. This already-implemented action was evaluated in a previous EA (DOE/EA-0990) prepared under the National Environmental Policy Act of 1969 (NEPA). Based on the analyses in the present EA, DOE has determined that the proposed action is not a major Federal action significantly affecting the quality of the human environment within the meaning of NEPA. Therefore, the preparation of an environmental impact statement (EIS) is not required, and DOE is issuing this Finding of No Significant Impact (FONSI).

\section{Public Availability:}

Copies of the EA and FONSI or further information on the DOE NEPA process are available from:
A. R. Grainger
SR NEPA Compliance Officer
Environmental Compliance Division
Savannah River Operations Office
P. O. Box 5031
Aiken, South Carolina 29804
Phone/FAX: (800) 242-8269
E-mail: nepa@barmS036.b-r.com

Background: SRS personnel are required under Occupational Safety and Health Administration regulations to wear protective clothing for activities involving the handling and removal of both lead and asbestos. This work can occur in both radiological and nonradiological areas on the site. Within the existing range of working conditions, these clothes can vary from minimal (e.g., coveralls without sleeves) to more advanced (e.g., coveralls with sleeves, hoods and booties) levels of protection.

Historically on SRS, once worker protective clothing had been used in either lead or asbestos handling/removal activities, it was not laundered but rather disposed of as waste in one of the site's waste management/disposal facilities. More recently, these garments have been appropriately containerized and placed in indefinite storage at SRS. With either the previous or current practices for dealing with the contaminated articles of protective clothing, replacement garments were provided for subsequent lead and asbestos handling/removal activities. The purpose of the proposed action is to provide SRS with a cost-effective means of meeting site needs for cleaning lead and asbestos contaminated controlled and routine protective clothing. 
Proposed Action: The proposed action is to transport the SRS-generated lead and asbestos contaminated protective clothing with the other site laundry to an off-site vendor facility having all required Nuclear Regulatory Commission, State, and local licenses and/or permits for cleaning. The laundered garments would then be reissued for use in SRS worker activities. The scope of the proposed action would be implemented within the existing contract for the cleaning of all of the site's controlled and routine laundry.

Approximately ten bags of lead and asbestos contaminated laundry are currently generated at SRS on an average monthly basis. In addition, approximately 120 bags of containerized contaminated laundry are currently in storage on site. After the stored inventory (approximately two percent of the current monthly site volume) has been laundered, the monthly increase over the present site generation volume would be less than 0.2 percent. The overall scope of the off-site commercial cleaning of SRS controlled and routine laundry was defined in the previously completed EA.

The location of the vendor's facility in Columbia, South Carolina, was used to estimate the impacts of transportation activities described in the EA. However, the potential currently exists for an off-site vendor laundry facility to be constructed at a new location (e.g., Aiken, South Carolina) along the analyzed route between SRS and the existing facility in Columbia. Should the off-site location change from the existing site to one along the analyzed route, the transportation impacts would be bounded by analyses presented in the EA.

Alternatives: In addition to the proposed action, DOE considered the following alternatives: (1) No Action (i.e., continue to store lead and asbestos contaminated laundry and provide replacement garments); and (2) dispose of the lead and asbestos contaminated laundry as waste. The no-action alternative would consist of continuing to containerize and store the lead and asbestos contaminated laundry per the current site practice, and to provide replacement garments. The site would continue to assume the cost of purchasing replacement garments. Further, the site would continue to accumulate bags of contaminated laundry at the rate of approximately ten bags per month. The impacts associated with the alternative of disposing of the subject laundry as waste in an appropriate manner were also analyzed. Although this alternative would meet the need for DOE action, it was not selected because of the resultant increases to the existing site waste streams (i.e., up to eight percent over the current level) and the continuing need to purchase replacement garments.

Environmental: The potential consequences of the proposed off-site commercial cleaning of SRS-generated lead and asbestos contaminated laundry were assessed to determine whether there would be any significant impacts to the following: water, air, and land resources; floodplains and wetlands; ecological and cultural resources; health and safety; socioeconomic conditions; and transportation. Aside from the existing negligible impacts associated with ongoing site laundry collection and distribution operations, no additional impacts are projected for site resources. The proposed action would not result in the loss of any lands on SRS. No impacts would be expected to occur to wetlands or sensitive ecological habitats, threatened or endangered species, or cultural resources. The transportation impacts were determined for the off-site shipment of the SRS generated lead and asbestos contaminated laundry to Columbia, South Carolina, for cleaning and return to SRS. Both incident-free and accident impacts for the subject shipments were analyzed. No latent cancer or accident-related fatalities would be expected to result from implementation of the proposed action.

Determination: Based on the information and analyses in the EA, DOE has determined that the proposed off-site commercial cleaning of lead and asbestos contaminated laundry 
generated at SRS does not constitute a major Federal action significantly affecting the quality of the human environment with the meaning of NEPA. Therefore, an EIS is not required and DOE is issuing this FONSI.

Signed in Aiken, South Carolina, this 20 day of 1995.

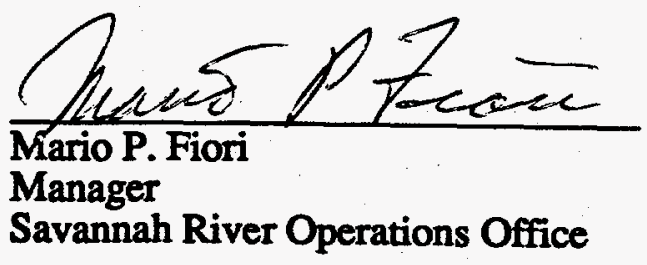


